\title{
Serological and molecular evidence of Brucella species in the rapidly growing pig sector in Kenya
}

\author{
James Akoko ${ }^{1,2^{*}} \mathbb{D}$, Roger Pelle ${ }^{2}$, Velma Kivali ${ }^{3}$, Esther Schelling ${ }^{4}$, Gabriel Shirima ${ }^{5}$, Eunice M. Machuka ${ }^{2}$, \\ Coletha Mathew ${ }^{6}$, Eric M. Fèvre ${ }^{3,7}$, Victoria Kyallo³, Laura C. Falzon ${ }^{3,7}$, AbdulHamid S. Lukambagire ${ }^{6}$, \\ Jo E. B. Halliday ${ }^{8}$, Bassirou Bonfoh ${ }^{9}$, Rudovick Kazwala ${ }^{6}$ and Collins Ouma ${ }^{1}$
}

\begin{abstract}
Background: Brucellosis is an emerging yet neglected zoonosis that has been reported in Kenya. Epidemiological data on brucellosis in ruminants is readily accessible; however, reports on brucellosis in pigs remain limited. This study sought to detect Brucella infection in pig serum by both serological and molecular techniques. Serum from 700 pigs randomly collected at a centralized abattoir in Nairobi region, Kenya were screened in parallel, using both Rose Bengal Test (RBT) and competitive Enzyme-Linked Immuno-sorbent Assay (cELISA) for antibodies against Brucella spp. All sera positive by RBT and 16 randomly selected negative samples were further tested using conventional PCR targeting bcsp31 gene and real-time PCR (RT-PCR) assays targeting IS711 and bcsp31 genes.

Results: A prevalence of $0.57 \%(n=4 / 700)$ was estimated using RBT; none of these samples was positive on cELISA. All RBT positive sera were also positive by both PCRs, while two sero-negative samples also tested positive on RTPCR $(n=6 / 20)$. Brucella abortus was detected in four out of the six PCR positive samples through a real-time multiplex PCR.

Conclusion: The detection of antibodies against Brucella spp. and DNA in serum from slaughterhouse pigs confirm the presence of Brucella in pigs. Therefore, investigation of the epidemiology and role of pigs in the transmission of brucellosis in Kenya is needed. Further targeted studies would be useful to systematically quantify and identify the spp. of Brucella in pigs.
\end{abstract}

Keywords: "Pig brucellosis", "Molecular detection", "Molecular evidence", Brucella, Serology, Kenya

\section{Background}

Brucellosis is a neglected zoonotic disease with a worldwide distribution [1]. It affects a broad range of wild and domesticated animals and is responsible for economic losses due to reduced milk yields, infertility and abortions in infected animals [2]. While there are numerous

\footnotetext{
* Correspondence: jamesakoko@yahoo.com

'Department of Biomedical Sciences and Technology, Maseno University, Kisumu, Kenya

${ }^{2}$ Biosciences Eastern And Central Africa - International Livestock Research Institute, Nairobi, Kenya

Full list of author information is available at the end of the article
}

species of the bacterial genus Brucella, those most commonly associated with human infections are $B$. melitensis, B. abortus and B. suis, largely affecting small ruminants, cattle, and pigs, respectively [3]. Over 500, 000 new human cases of brucellosis are reported annually globally [4]. Humans can get infected with brucellosis via direct or indirect contact with infected animals and through the consumption of undercooked or raw animal products. Therefore, control of brucellosis in animals can reduce new cases of human brucellosis. In Kenya, brucellosis is among the top priority zoonotic

(c) The Author(s). 2020 Open Access This article is licensed under a Creative Commons Attribution 4.0 International License, which permits use, sharing, adaptation, distribution and reproduction in any medium or format, as long as you give appropriate credit to the original author(s) and the source, provide a link to the Creative Commons licence, and indicate if changes were made. The images or other third party material in this article are included in the article's Creative Commons licence, unless indicated otherwise in a credit line to the material. If material is not included in the article's Creative Commons licence and your intended use is not permitted by statutory regulation or exceeds the permitted use, you will need to obtain permission directly from the copyright holder. To view a copy of this licence, visit http://creativecommons.org/licenses/by/4.0/ The Creative Commons Public Domain Dedication waiver (http://creativecommons.org/publicdomain/zero/1.0/) applies to the data made available in this article, unless otherwise stated in a credit line to the data. 
diseases for integrated 'One Health' control, but the focus is limited to ruminants, for which data on their importance as a significant source of human infection with Brucella is available $[5,6]$.

The species, B. suis, is considered as one of the three most common zoonotic pathogenic species to humans [1]. Nonetheless, data on the epidemiology of pig brucellosis in Kenya remains very sparse, with no recently generated reports. The only documented information on pig brucellosis was produced more than four decades ago, through a serological survey that reported the presence of Brucella antibodies in pigs with a prevalence of $0.2 \%$ [7]. Despite this, pork production and consumption are among the most rapidly growing livestock sectors in Kenya, with a predicted overall production growth rate of $203 \%$ for the period between 2000 and 2030 [8].

The Rose Bengal test (RBT) is the World Organisation for Animal Health (OIE) recommended screening test for brucellosis in animals [9]. However, several studies have reported false positivity with this test due to cross interaction with $Y$. enterocolitica O:9, which is quite prevalent in pig populations $[10,11]$. The confirmation of the RBT by Enzyme-Linked Immuno-Sorbent Assays (ELISAs) also suffers from reportedly low sensitivity in pig sera $[10,11]$. These limitations generally suggest that serological testing of pig serum with the recommended tests may not be ideal and that results should, therefore, be interpreted with caution.

The development of molecular-based assays for the rapid and specific detection of Brucella DNA has significantly advanced our understanding of host-pathogen interactions. Previous serology-based surveys traditionally assumed that Brucella spp. have host preference [10, 11]. Recent studies have shown that there is indeed a complex and diverse distribution of the pathogen among different hosts, further complicated by farming systems and close interactions between wildlife and livestock [12]. Quantitative, real-time PCR assays, such as those developed by Matero et al. [13] and Probert et al. [14], have also significantly increased the ease of detection of Brucella DNA, moreover, with the extraction of genomic material directly from clinical specimens [15]. These test options and findings have shed light on the complicated epidemiology and transmission of brucellosis between different hosts which, unfortunately, have not been applied to the pig population in sub-Saharan Africa. There is a scarcity of reported studies in Africa in detecting brucellosis in pigs by molecular techniques, besides the insufficient information on $B$. suis infection in the region. Therefore, the understanding of the role of pigs in the transmission dynamics of brucellosis remains limited. Previous studies have looked into pork value chains and their potential role in the transmission of other priority zoonoses $[16,17]$. This study was therefore done to detect and identify Brucella spp. in pigs entering the Nairobi pork market. In so doing, we identified exciting variations to our current understanding of host species distributions and diagnostic challenges for brucellosis in pigs.

\section{Results}

A total of 700 pigs were sampled at a central abattoir [16]. Pigs from all over Kenya were eligible for inclusion in the study; most sampled pigs originated from the central region $(n=427 ; 61 \%)$ and Nairobi $(n=159 ; 22.7 \%)$. Majority of the sampled pigs were female $(n=469$; $67.0 \%)$. The pig sera were tested for antibodies against Brucella spp. using RBT and cELISA. Four out of the seven hundred sera tested by RBT were positive, while none were positive by cELISA (Table 1 ). The four RBT positive samples, together with 16 randomly selected RBT negative samples were also tested by PCR for detection of Brucella spp. DNA.

Out of the 20 samples selected for molecular analysis, 4 samples amplified the target region of interest on molecular testing using conventional PCR, giving an anticipated band of 223 base pairs. Data shown in Additional file 1: (Detection of Brucella DNA using conventional PCR method: Electronic supplementary material).

Six out of the 20 samples tested by real-time PCR amplified with both the bcsp31 and the IS711 genusspecific primers used to detect the presence of Brucella DNA. Amplification with the B. abortus primers was also achieved with 4 of these 6 samples. None of the samples amplified with the B. melitensis specific primers (Table 2).

\section{Discussion}

We detected the presence of Brucella DNA in pig sera that also screened positive using the RBT. According to our knowledge, this is the first report of molecular detection of Brucella spp. in pig serum in East Africa. Brucellosis is a widespread zoonotic disease and serological evidence of pig brucellosis has previously been described in Africa [15, 18-22]. However, information on B. spp. circulating in the pig population remains limited. South America and Southeast Asia are considered to have a higher prevalence of porcine brucellosis, as compared to the other regions, including Africa [1]. The seropositivity of $0.57 \%$ detected in this study is consistent with findings from different serological studies conducted in other African countries such as Nigeria [19, 20, 22], Zambia [22] and Uganda [20], which reported prevalence of between 0 and $0.6 \%$. However, our results differ with one study that reported a high sero-prevalnce of $30.6 \%$ in Benue State of Nigeria [21]. The high prevalence reported in Benue State, however, could be due to the clustering of positive animals in the targeted region, as other studies in Nigeria also reported lower 
Table 1 Serological and molecular detection of Brucella antibodies and DNA in pig sera in Kenya

\begin{tabular}{lll}
\hline Test performed & Number tested & Number/proportion of positive \\
\hline RBT & 700 & $4(0.57 \%)$ \\
CELISA & 700 & $0(0.00 \%)$ \\
Conventional PCR, genus specific target (bcsp31) & 20 & $4(20.00 \%)$ \\
qPCR, IS711 and bcsp31targets & 20 & $6(30.00 \%)$ \\
qPCR, B. abortus specific target (alkB) & 6 & $4(66.67 \%)$ \\
qPCR, B. melitensis specific target (BMEI1162) & 6 & $0(0.00 \%)$ \\
\hline
\end{tabular}

prevalence rates $[18,23]$. Despite the low prevalence of $0.57 \%$ detected from the pig population in this study, the risk of transmission in the pig population may grow with the rapidly growing pig production in Kenya, especially if control interventions are not put into place.

In this study, we found that four out of the six positive samples detected were of $B$. abortus, as they amplified with $B$. abortus primers [14]. The other two samples that did not amplify with the species identification primers could belong to a different species, given that the assay is designed to distinguish between $B$. abortus and $B$. melitensis [14]. The detection of zoonotic Brucella spp. in pig sera, and more so B. abortus, is of importance given that pigs are traditionally associated with $B$. suis, while cattle are considered to be the preferred host for B. abortus [1]. This finding therefore highlights the possibility for novel transmission dynamics within pigs and the need for further investigations to inform appropriate control strategies for brucellosis in Kenya and similar settings. The number of studies that have used serum samples for extraction of genomic DNA, and subsequent detection of Brucella DNA, has increased in the recent past $[13,15,20]$. This could be due to the fact that serum samples can be used for routine testing of brucellosis in both animals and humans since, unlike other samples such as abortion materials, swabs, hygromas and milk, they are not affected by the age, sex or physiological stage (such as pregnancy). Even though Brucella spp. are known to have host preference, cross-infection has previously been reported to be common in areas where mixed husbandry systems are practised [11, 24, 25].

Similarly, the presence of $B$. melitensis in pigs' serum was recently reported in Egypt [15]. In that study, the prevalence was comparable to a previous report from Latin America where $B$. melitensis was detected in pigs [26]. In the current study, the positive pigs were sourced from peri-urban and slum areas, where small-scale farmers keep mixed herds that facilitates close contact between the different animal species. Free-range systems practised in the informal settlements, and feeding of pigs on waste from the market [27] could also contribute to the cross-transmission of $B$. abortus from cattle to pigs. The presence of $B$. abortus in pigs may not only present a zoonotic risk to non-suspecting farmers, slaughterhouse workers and pork consumers but also raises the need for further investigation on the epidemiology and pathogenicity of $B$. abortus in pigs, as well as their contribution to human infection.

The Rose Bengal Test (RBT), Buffered Plate Agglutination Test (BPAT) and ELISA are recommended serological tests for screening brucellosis in pigs [1]. However, the results from these tests should be confirmed by reference serology tests or confirmatory bacteriology and molecular techniques [10, 11, 28, 29]. Variability between the performance of different

Table 2 Results for RBT and Real-Time PCR positive samples $(n=6)$

\begin{tabular}{|c|c|c|c|c|c|c|c|}
\hline Samples & Source & Sex & RBT results & Conventional PCR & $\begin{array}{l}\text { Genus specific (IS711\& } \\
\text { bcsp31) }\end{array}$ & $\begin{array}{l}\text { B. } \\
\text { abortus } \\
\text { specific }\end{array}$ & $\begin{array}{l}\text { B. } \\
\text { melitensis } \\
\text { specific }\end{array}$ \\
\hline Serum & $\begin{array}{l}\text { Central region } \\
\text { Peri-urban }\end{array}$ & Female & -ve & not done & +ve & +ve & -ve \\
\hline Serum & $\begin{array}{l}\text { Rift valley region } \\
\text { Peri-urban }\end{array}$ & Female & +ve & +ve & +ve & -ve & -ve \\
\hline Serum & $\begin{array}{l}\text { Central region } \\
\text { Peri-urban }\end{array}$ & Female & +ve & +ve & +ve & -ve & -ve \\
\hline Serum & $\begin{array}{l}\text { Western region } \\
\text { Peri-urban }\end{array}$ & Male & -ve & not done & +ve & $+\mathrm{ve}$ & -ve \\
\hline Serum & $\begin{array}{l}\text { Central region } \\
\text { peri-urban }\end{array}$ & Male & +ve & +ve & +ve & $+\mathrm{ve}$ & -ve \\
\hline Serum & $\begin{array}{l}\text { Nairobi region } \\
\text { Slum }\end{array}$ & Male & +ve & +ve & +ve & +ve & -ve \\
\hline
\end{tabular}


serological tests, or in the sensitivities and specificities for the same tests using pig serum in different studies, have been recorded $[28,30,31]$. This study also observed a poor agreement between the RBT and cELISA, which is similar to the findings in other studies [30,31]. Further investigation should be carried out to evaluate the performance of these two assays on pig samples. There was a much better agreement between the conventional and qPCR. All four positive samples detected by conventional PCR (B4/B5 primers) were further confirmed by a multi-level genus- and species-specific RTPCR. Brucella abortus was identified in four of the six positive samples. The agreement between molecular and serological tests raises an important consideration for these tests to be used for routine testing (surveillance) of brucellosis in livestock and wildlife.

This study had several limitations; first, not all 700 sera screened by the RBT and cELISA were tested by PCR. This could downplay the positivity proportion detected in the molecular assays used. Secondly, the time lapse between the serology (September 2018) and molecular testing (November 2019) implies that study personnel were not entirely blinded to the results of the initial screening when conducting PCR. Finally, the limited scope of the species identification technique used (B. abortus and B. melitensis) could imply that other Brucella spp., including a possibly novel species in this pig population, could have been missed in this study. Future studies should consider the suitability of different assays for the detection of pig brucellosis since it is an emerging area of research. All the assays used in this study are not explicitly designed for pig host testing, rather the assays are generally applied to the detection of Brucella antibodies and DNA. This could affect the sensitivity or specificity of detecting brucellosis in pigs, especially when a single test is used. Therefore, future studies should evaluate a range of tests for utility in testing for brucellosis within this crucial population.

\section{Conclusion}

Brucella antibodies and DNA were detected in pig sera from slaughterhouses in Nairobi, Kenya. Further targeted studies to systematically quantify and speciate the strain of Brucella in pigs should be conducted.

\section{Methods}

\section{Study site}

The study was conducted at the largest pig abattoir that supplies unprocessed pork to consumers in the city of Nairobi. The abattoir is located at the outskirts of Nairobi and obtains pigs from all production regions in Kenya.

\section{Sampling and data collection}

A total of 700 blood samples were collected from pigs in a prevalence study on pig cysticercosis, as previously described [16]. All pigs presented for slaughter from the months of October to December 2014 were eligible for sampling [16]. Based on the data available from Kenya at the time of the parent study design, an assumed prevalence of $32.8 \%$ was used, with a $95 \%$ confidence level and a precision of $5 \%$, to obtain an adequate sample size for the estimation of the population prevalence of cysticercosis [16]. Pigs were systematically selected; the first pig presented for slaughter was sampled, followed by every fifth, to get an average of 15 pigs each day for 47 days. Approximately $10 \mathrm{ml}$ of blood were collected from each pig into a plain vacutainer tube (BD Vacutainer). A brief questionnaire was administered to the pig owner (farmers or traders), to capture information including the origin/location, sex, and age of the sampled pigs. The blood samples were temporarily stored at $2-8{ }^{\circ} \mathrm{C}$ before transportation to the International Livestock Research Institute (ILRI) laboratories in Nairobi, Kenya. The samples were then centrifuged at $2500 \mathrm{rpm}$ for 20 min and serum aliquoted into $2 \mathrm{ml}$ sample tubes for storage at $-80^{\circ} \mathrm{C}$ until testing.

\section{Serological testing \\ Rose Bengal test (RBT)}

The Rose Bengal Test (RBT) was carried out using antigens provided by Instituto de Salud Tropical Universidad de Navarra @ Edificio CIMA AvdaPioXII, 55 E31008 Pamplona, Spain. The testing was carried out according to the OIE protocol [9]. Briefly, all 700 serum samples and the antigen were defrosted at room temperature. About $25 \mu \mathrm{l}$ of the sample was dispensed onto the glossy side of a white tile. An equal volume of the antigen was then dispensed beside each drop of serum. Each plate was prepared with negative and positive controls also provided with the kit. The antigen and serum were immediately mixed using a wooden splint, and the plate rocked gently for 4 minutes. Following this, the results were read immediately in a well-lit place and interpreted as either positive or negative. Samples were considered positive for RBT when there was any degree of visible agglutination at 4 minutes [9].

\section{Competitive enzyme-linked immunosorbent assay (cELISA) testing}

The ELISA testing was done on all the 700 samples using competitive ELISA kit, COMPELISA 400 (cELISA APHA Scientific, Weybridge-UK) for detection of antiBrucella antibodies. The cELISA testing was conducted as per the manufacturer's instructions as follows; all reagents and serum samples were first brought to room temperature. Serum samples $(20 \mu \mathrm{l})$ were added to each 
well of the ELISA plates that are pre-coated with purified standard sLPS antigen prepared from $B$. melitensis isolates and mixed with $100 \mu \mathrm{l}$ of the freshly prepared conjugate. Positive and negative controls were included in each test run. After incubation at room temperature for $30 \mathrm{~min}$ and constant mixing on a rotary shaker, the plates were washed five times with the wash solution. Then $100 \mu \mathrm{l}$ of chromogen substrate was added to each of the wells, incubated at room temperature for $15 \mathrm{~min}$ and the reaction stopped by adding $100 \mu \mathrm{l}$ of stopping solution to each well. The Optical Density (OD) was determined using an ELISA reader (BioTek Synergy HT, BioTek Winooski, VT 05404 United States) at a wavelength of $450 \mathrm{~nm}$. A plate was considered valid if the mean OD of the 6 negative controls at $450 \mathrm{~nm}$ was greater than 0.700 , and the mean OD of the 6 positive controls was less than 0.100 [32]. The difference between the OD of the positive and negative controls had to be equal to or greater than 0.300 . A cut-off was determined using the conjugate control, i.e. $60 \%$ of the mean OD of the four conjugate control wells $[28,30]$. Any OD equal to or below the determined cut-off value was considered as being positive, while values above cut-off were considered negative [32].

\section{Molecular detection Sample selection}

The RBT positive samples plus additional randomly selected RBT negative samples (4 RBT negative sera selected for each of the RBT positive samples), were processed for molecular testing. We estimated the sample size based on the sample required to detect a minimum number of 4 positive events at a $95 \%$ confidence, given a positivity of $33 \%$. This gave us a minimum sample estimate of 20 . All the molecular testing was conducted at ILRI between November and December 2019.

\section{Extraction and purification of DNA}

Extraction of genomic DNA was done from $200 \mu \mathrm{l}$ of the serum using QIAamp ${ }^{\text {Tn }}$ DNA Mini Kit, (QIAGEN,
Germany), according to the manufacturer's guidelines. Briefly, $20 \mu \mathrm{l}$ of proteinase $\mathrm{K}$ and $200 \mu \mathrm{l}$ of genomic lysis buffer were added to the source sample. The mixture was subjected to digestion, deactivation, washing and elution steps as per the manufacturer's guidelines. The DNA quality and quantity were determined using a NanoDrop $^{\text {tw }}$ 2000c Spectrophotometer (ThermoFisher Scientific, USA). Stock DNA samples were stored at $20^{\circ} \mathrm{C}$ until the performance of PCR.

\section{Conventional PCR detection of Brucella DNA}

Molecular identification of the genus Brucella was done using two sets of primers: B4 forward $\left(5^{\prime}\right.$-TGG CTC GGT TGC CAA TAT CAA-3') and B5 reverse (5'-CGC GCT TGC CTT TCA GGT CTG-3), as previously reported [29].

\section{Real-time PCR detection of Brucella DNA}

Real-time PCR was performed on all the extracted DNA samples using an ABI 7500 thermocycler machine (Applied Biosystems, Life Technologies, Singapore), beginning with a Brucella genus-level screening using two primers targeting IS711 gene and bcsp31 gene, respectively $[13,14]$. The species identification using $B$. abortus and $B$. melitensis-specific primers and probes, was subsequently performed on DNA samples that showed any amplification with both targets bcsp31 and IS711 primers. This second round multiplex $\mathrm{qPCR}$ was performed using previously developed oligonucleotide primers and probes [14] as indicated in Table 3 below. Briefly, template DNA $(4 \mu \mathrm{l})$ were mixed with $0.5 \mu \mathrm{M}$ each of the primers targeting the alkB for Brucella abortus, BMEI1162 for B. melitensis and $0.25 \mu \mathrm{M}$ of fluorescent probe (primer and probe sequences are given in Table 3). About $10 \mu \mathrm{l}$ of the Luna ${ }^{\circ}$ Universal Probe qPCR mastermix (404 with UDG; New England BioLabs, MA, USA) was added to each oligonucleotide and DNA sample mixture. The reaction mixture $(20 \mu \mathrm{l})$ was then run on an Applied Biosystems 7500 Real-Time PCR System (Applied Biosystems, USA). All the samples and

Table 3 Primers and probes used for real-time PCR

\begin{tabular}{|c|c|c|c|c|}
\hline Target & Gene targeted & Sequences of primers and probes $\left(5^{\prime}-3^{\prime}\right)$ & Fluorophore/ quencher & Reference \\
\hline Genus Brucella & 15711 & $\begin{array}{l}\text { Forward GGCCTACCGCTGCGAAT } \\
\text { Reverse TTGCGGACAGTCACCATAATG } \\
\text { Probe AAGCCAACACCCGGC }\end{array}$ & FAM/-MGBNFQ & Matero, 2011 [13] \\
\hline Genus Brucella & Bcsp31 & $\begin{array}{l}\text { Forward GCTCGGTTGCCAATATCAATGC } \\
\text { Reverse GGGTAAAGCGTCGCCAGAAG } \\
\text { Probe AAATCTTCCACCTTGCCCTTGCCATCA }\end{array}$ & 6-FAM/BHQ1 & Probert, 2004 [14] \\
\hline B. abortus & IS711 downstream of alkB & $\begin{array}{l}\text { Forward GCGGCTTTTCTATCACGGTATTC } \\
\text { Reverse CATGCGCTATGATCTGGTTACG } \\
\text { Probe CGCTCATGCTCGCCAGACTTCAATG }\end{array}$ & JOE/BHQ1 & \\
\hline B. melitensis & IS711 downstream of BMEI1162 & $\begin{array}{l}\text { Forward AACAAGCGGCACCCCTAAAA } \\
\text { Reverse CATGCGCTATGATCTGGTTACG } \\
\text { Probe CAGGAGTGTTTGGCTCAGAATAATCCACA }\end{array}$ & Texas Red/BHQ2 & \\
\hline
\end{tabular}


control mixtures were tested in duplicate using the following parameters: $2 \mathrm{~min}$ of decontamination at $95^{\circ} \mathrm{C}$, followed by $10 \mathrm{~min}$ of denaturation and activation of polymerase at $95^{\circ} \mathrm{C}$, then 45 cycles of $95^{\circ} \mathrm{C}$ for $15 \mathrm{~s}$ and $57^{\circ} \mathrm{C}$ for $1 \mathrm{~min}$. A sample was considered positive if it amplified in one or both wells with a cycle threshold $(\mathrm{Ct})$ values $<39$. Positive controls $16 \mathrm{M} \mathrm{B}$. melitensis and 544 B. abortus (sourced from Friedrich-LoefflerInstitute, the Brucella reference lab in Germany) and non-template controls were included in all the real-time PCR runs.

\section{Supplementary information}

Supplementary information accompanies this paper at https://doi.org/10. 1186/s12917-020-02346-y.

Additional file 1. Detection of Brucella DNA using conventional PCR method.

\section{Abbreviations}

cELISA: Competitive Enzyme-Linked Immuno-sorbent Assay; DNA: Deoxyribonucleic acid; ILRI: International Livestock Research Institute; OD: Optical Density; OIE: World Organisation for Animal Health; RBT: Rose Bengal Test; RT-PCR: Real Time Polymerase Chain Reaction

\begin{abstract}
Acknowledgements
We gratefully acknowledge Prof. Heinrich Neubauer and Dr. Falk Melzer from Friedrich-Loeffler-Institute, the Brucella reference lab in Germany, for providing the positive controls used for the molecular analysis. We also thank Prof. Ignacio Moriyón for the provision of Rose Bengal reagent and controls from Instituto de Salud Tropical Universidad de Navarra @ Edificio CIMA AvdaPioXII, 55 E-31008 Pamplona, Spain. The study would not have been possible without the support from the Veterinary Department, the abattoir owners, meat inspectors and pig owners in Nairobi, Kenya.
\end{abstract}

\section{Authors' contributions}

Concept development; JA, CO, ES, GS, RK, LF, EF, BB, Formal analysis; JA, JH, $A L, E M, C O$, Funding acquisition; BB, RK, EF RP, Investigation; JA, VK1, VK2, CO, $R P$, Methods; JA, JH, ES, RP, EM, AL, CM, VK1, Supervision; CO, RP, GS, ES EF, writing - original draft; JA, VK2, AL, Writing - review \& editing; All Authors. The authors read and approved the final manuscript.

\section{Funding}

JA, CM, AL were supported within the framework of the DELTAS Africa Initiative [Afrique One-ASPIRE /DEL-15-008]. The Medical Research Council (UK) supported data collection and serological analysis, Biotechnology and Biological Science Research Council (UK), the Economic and Social Research Council (UK), the Natural Environment Research Council (UK), through the Environmental \& Social Ecology of Human Infectious Diseases Initiative (ESEI), Grant Reference: G1 100783/1 and the CGIAR Research Program on Agriculture for Nutrition and Health $(\mathrm{A} 4 \mathrm{NH})$, led by the International Food Policy Research Institute (IFPRI); we acknowledge the CGIAR Fund Donors (https:// www.cgiar.org/funders/). The molecular assays were conducted at the BecAILRI Hub through the Africa Biosciences Challenge Fund (ABCF) fellowship. The ABCF program is funded by the Australian Department for Foreign Affairs and Trade (DFAT) through the BecA-CSIRO partnership; the Syngenta Foundation for Sustainable Agriculture (SFSA); the Bill \& Melinda Gates Foundation (BMGF); the UK Department for International Development (DFID) and the Swedish International Development Co-operation Agency (Sida). The funders had no role in the design of the study, data collection, analysis, interpretation, writing or decision on the choice for the journal.

Availability of data and materials

All the analysed data are included in this article and its supplementary files.

\section{Ethics approval and consent to participate}

The project was reviewed and approved by the International Livestock Research Institute (ILRI) Institutional Animal Care and Use Committee (IACUC Ref No. 2014.34) [16]. Oral and written informed consent was sought from pig owners before conducting interviews and sample collection.

\section{Consent for publication}

Not applicable.

\section{Competing interests}

No known competing interests. The funders did not influence the design, conduct and reporting of these findings.

\section{Author details}

${ }^{1}$ Department of Biomedical Sciences and Technology, Maseno University, Kisumu, Kenya. ${ }^{2}$ Biosciences Eastern And Central Africa - International Livestock Research Institute, Nairobi, Kenya. ${ }^{3}$ International Livestock Research Institute, Nairobi, Kenya. ${ }^{4}$ Department of Public Health and Epidemiology, Swiss Tropical Institute, Basel, Switzerland. ${ }^{5}$ Nelson Mandela African Institute of Science and Technology, Arusha, Tanzania. ${ }^{6}$ Sokoine University of Agriculture, Morogoro, Tanzania. ${ }^{7}$ Institute of Infection and Global Health, University of Liverpool, Liverpool, UK. ${ }^{8}$ University of Glasgow, Glasgow, UK. ${ }^{9}$ Centre Suisse de Recherches Scientifiques en Côte d'Ivoire, Neuchâtel, Switzerland.

Received: 21 January 2020 Accepted: 29 April 2020

Published online: 11 May 2020

\section{References}

1. Corbel MMJ. Brucellosis in humans and animals. WHO Libr Cat Publ Data. 2006:1-88 Available from: https://www.who.int/csr/resources/Brucellosis.pdf.

2. McDermott JJ, Grace D, Zinsstag J. Economics of brucellosis impact and control in low-income countries. Sci Tech Rev Off Int des Epizoot. 2013; 32(1):249-61 Available from: http://europepmc.org/abstract/MED/238373 82\%5Cnpapers3://publication/uuid/2D763777-4D69-4CA5-B587-C1FA6C704 DBO.

3. Franc KA, Krecek RC, Häsler BN, Arenas-Gamboa AM. Brucellosis remains a neglected disease in the developing world: a call for interdisciplinary action. BMC Public Health. 2018;18(1):1-9.

4. Pappas G, Papadimitriou P, Akritidis N, Christou L, Tsianos EV. The new global map of human brucellosis. Lancet Infect Dis. 2006. Available from. https://doi.org/10.1016/S1473-3099(06)70382-6.

5. Munyua P, Bitek A, Osoro E, Pieracci EG, Muema J, Mwatondo A, et al. Prioritization of zoonotic diseases in Kenya, 2015. PLoS One. 2016;11(8):1-11. Available from:. https://doi.org/10.1371/journal.pone.0161576.

6. Njeru J, Wareth G, Melzer F, Henning K, Pletz MW, Heller R, et al. Systematic review of brucellosis in Kenya: disease frequency in humans and animals and risk factors for human infection. BMC Public Health. 2016;16(1):1-15. Available from:. https://doi.org/10.1186/s12889-016-3532-9.

7. Waghela S, Fazil MA, Gathuma JM, Kagunya DK. A serological survey of brucellosis in camels in north-eastern province of Kenya. Tropl Anim Health Prod. 1978;10(1):28-9.

8. Robinson T, Pozzi F. Mapping supply and demand for animal-source foods to 2030. Animal production and health working paper. No. 2; 2011. Available from: http://www.fao.org/3/i2425e/i2425e00.htm.

9. OIE. Brucellosis (B. abortus, B.melitensis and B. suis); 2016. Available from: https://www.oie.int/en/animal-health-in-the-world/animal-diseases/ Brucellosis/.

10. World Health Organization. Brucellosis in humans and animals: WHO guidance: WHO Library. World Health Organization; 2006. Available from: http://www.who.int/csr/resources/publications/deliberate/WHO_CDS_EPR_2 006 _7/en/.

11. Verger J-M, Grimont F, Gmont PAD, Brucella GM. A monospecific genus as shown by deoxyribonucleic acid hybridization. Int J Syst Bacteriol. 1985; 35(3):292-5 Available from: http://ijs.sgmjournals.org/content/35/3/292. abstract.

12. Shirima GM, Kunda JS. Prevalence of brucellosis in the human, livestock and wildlife interface areas of Serengeti National Park, Tanzania. Onderstepoort J Vet Res. 2016:83(1):2-5 Available from: http://ojvr.org/index.php/ojvr/article/ view/1032. 
13. Matero $P$, Hemmilä H, Tomaso H, Piiparinen $H$, Rantakokko-Jalava K, Nuotio $L$, et al. Rapid field detection assays for Bacillus anthracis, Brucella spp. Francisella tularensis and Yersinia pestis. Clin Microbiol Infect. 2011. Available from. https://doi.org/10.1111/j.1469-0691.2010.03178.x.

14. Probert W, Schrader KN, Khuong NY, Bystrom SL, Graves MH. Real-time multiplex PCR assay for detection of Brucella spp. J Clin Microbiol. 2004; 42(3):1290-3.

15. Khan AU, Melzer F, El-Soally SAGE, Elschner MC, Mohamed SA, Ahmed MAS, et al. Serological and molecular identification of brucella spp. in pigs from Cairo and Giza governorates, Egypt. Pathogens. 2019;8(4):1-7.

16. Akoko JM, MacLeod E, Thomas LF, Alarcon P, Kang'ethe E, Kivali V, et al. Detection of circulating antigens for Taenia spp. in pigs slaughtered for consumption in Nairobi and surroundings, Kenya. Parasite Epidemiol Control. 2019;4. Available from. https://doi.org/10.1016/j.parepi.2019.e00093.

17. Alarcon P, Dominguez-Salas P, Häsler B, Rushton J, Alarcon P, Fèvre EM, et al. Mapping of beef, sheep and goat food systems in Nairobi - a framework for policy making and the identification of structural vulnerabilities and deficiencies. Agr Syst. 2017;152:1-17.

18. Onunkwo JI, Njoga EO, Nwanta JA, Shoyinka SVO, Onyenwe IW, EJ. Serological Survey of Porcine Brucella infection in south East Nigeria. Niger Vet J. 2011;32(1):60-2.

19. Nwanta JA, Shoyinka SVO, Chah KF, Onunkwo Jl, Onyenwe IW, Eze Jl, et al. Production characteristics, disease prevalence, and herd-health management of pigs in Southeast Nigeria. J Swine Heal Prod. 2011;19(6):331-9 Available from: https://www.aasv.org/jshap/issues/v19n6/v19n6p331.pdf.

20. Erume J, Roesel K, Dione MM, Ejobi F, Mboowa G, Kungu JM, et al. Serological and molecular investigation for brucellosis in swine in selected districts of Uganda. Tropl Anim Health Prod. 2016;48(6):1147-55. Available from:. https://doi.org/10.1007/s11250-016-1067-9.

21. Ngbede EO, Momoh AH, Bala RS, Madaki BD, Maurice AN. An abattoir-based study on serodiagnosis of swine brucellosis in Makurdi, Benue state, northCentral Nigeria. J Adv Vet Res. 2013;3(2):57-9 Available from: https://www. researchgate.net/publication/306287135.

22. Stafford. Antibodies to some swine disease in commercial piggeries in Central Zambia; 1992. Available from: https://www.ncbi.nlm.nih.gov/ pubmed/1339985.

23. Cadmus SI, ljagbone I, Oputa H, Adesokan H, Stack J. Serological survey of brucellosis in livestock animals and workers in Ibadan, Nigeria. Afr J Biomed Res. 2009;9(3):163-8.

24. Godfroid J, Garin-Bastuji B, Saegerman C, Blasco JM. Brucellosis in terrestrial wildlife. Rev Sci Tech Off Int Epiz. 2013;32(321):27-42

25. Ducrotoy M, Bertu W, Matope G, Cadmus S, Conde-Álvarez R, Gusi AM, et al. Brucellosis in sub-Saharan Africa: current challenges for management, diagnosis and control. Acta Trop. 2015;165:179-93. Available from:. https:// doi.org/10.1016/j.actatropica.2015.10.023.

26. Lucero NE, Ayala SM, Escobar GJ, Jacob NR. Brucella isolated in humans and animals in Latin America from 1968 to 2006. Epidemiol Infect. 2008;136(4): 496-503.

27. Alarcon P, Fèvre EM, Muinde P, Murungi MK, Kiambi S, Akoko J, et al. Urban livestock keeping in the city of Nairobi: diversity of production systems, supply chains, and their disease management and risks. Front Vet Sci. 2017;4(OCT):171.

28. Praud A, Gimenez O, Zanella G, Dufour B, Pozzi N, Antras V, et al. Estimation of sensitivity and specificity of five serological tests for the diagnosis of porcine brucellosis. Prev Vet Med. 2012;104(1-2):94-100. Available from: https://doi.org/10.1016/j.prevetmed.2011.10.014.

29. G.G. Baily, J. B Krahn BSD and NGSt. Detection of Brucella melitensis and Brucella abortus by DNA amplification; 1992. Available from: https://www. ncbi.nlm.nih.gov/pubmed/1495123.

30. Praud A, Gimenez O, Zanella G, Pozzi N, Antras V, Meyer L, et al. Evaluation of five serological tests for the diagnosis of porcine brucellosis in French Polynesia. Tropl Anim Health Prod. 2013;45(4):931-3.

31. Muñoz PM, Blasco JM, Engel B, de Miguel MJ, Marín CM, Dieste L, et al. Assessment of performance of selected serological tests for diagnosing brucellosis in pigs. Vet Immunol Immunopathol. 2012;146(2):150-8.

32. APHA Scientific. COMPELISA $160 \& 400$ a competitive ELISA kit for the detection of antibodies against Brucella in serum samples INSTRUCTIONS FOR USE (for in-vitro and animal use only); 2014. p. 1-4.

\section{Publisher's Note}

Springer Nature remains neutral with regard to jurisdictional claims in published maps and institutional affiliations.

\section{Ready to submit your research? Choose BMC and benefit from:}

- fast, convenient online submission

- thorough peer review by experienced researchers in your field

- rapid publication on acceptance

- support for research data, including large and complex data types

- gold Open Access which fosters wider collaboration and increased citations

- maximum visibility for your research: over $100 \mathrm{M}$ website views per year

At BMC, research is always in progress.

Learn more biomedcentral.com/submissions 